\title{
Wandonia haliotis gen. nov., sp. nov., a marine bacterium of the family Cryomorphaceae, phylum Bacteroidetes
}

Correspondence

Hyung-Yeel Kahng

kahng@sunchon.ac.kr

\author{
Dong-Heon Lee, ${ }^{1}$ Eun-Kyoung Choi, ${ }^{1}$ Sung-Ran Moon, ${ }^{1}$ Samyoung Ahn, ${ }^{1}$ \\ Young Sun Lee, ${ }^{2}$ Jae Sung Jung, ${ }^{2}$ Che Ok Jeon, ${ }^{3}$ Kyung-Sook Whang ${ }^{4}$ \\ and Hyung-Yeel Kahng ${ }^{1}$ \\ 1Department of Environmental Education, Sunchon National University, Sunchon 540-742, \\ Republic of Korea \\ ${ }^{2}$ Department of Life Science, Sunchon National University, Sunchon 540-742, Republic of Korea \\ ${ }^{3}$ Department of Life Science, Chung-Ang University, Seoul 156-756, Republic of Korea \\ ${ }^{4}$ Division of Bio and Health Science, Mokwon University, Daejeon 302-729, Republic of Korea
}

\begin{abstract}
A novel, strictly aerobic, Gram-stain-negative, yellow-orange-pigmented, rod-shaped bacterium was isolated from abalone (Haliotis discus) under aquaculture in seawater off the Wando coast, Southern Korea, and subjected to a polyphasic taxonomic study. Cells of strain Haldis $-1^{\top}$ were catalase- and oxidase-positive rods with flexirubin pigments. Phylogenetic analysis based on $16 \mathrm{~S}$ rRNA gene sequences revealed that strain Haldis $-1^{\top}$ formed a distinct lineage within the family Cryomorphaceae and could be distinguished from the related genera Lishizhenia and Fluviicola. Strain Haldis $-1^{\top}$ shared $16 \mathrm{~S}$ rRNA gene sequence similarities of 92.5 and $92.4 \%$ with Lishizhenia caseinilytica UST040201-001 ${ }^{\top}$ and Fluviicola taffensis RW262 ${ }^{\top}$, respectively. The DNA G $+\mathrm{C}$ content was $38.1 \mathrm{~mol} \%$ and the major respiratory quinone was MK-7. The predominant cellular fatty acids were iso- $\mathrm{C}_{15: 0}(38.6 \%), \mathrm{C}_{15: 0} 2-\mathrm{OH}(20.3 \%)$ and $\mathrm{C}_{15: 0}$ (10.7\%). Growth was observed at $25-42{ }^{\circ} \mathrm{C}$ (optimum $30-37{ }^{\circ} \mathrm{C}$ ) and at $\mathrm{pH} 6.5-9.5$ (optimum $\mathrm{pH}$ 6.5-8.0). On the basis of polyphasic analysis of phenotypic, genotypic and phylogenetic data, strain Haldis $-1^{\top}$ represents a novel genus and species within the family Cryomorphaceae in the phylum Bacteroidetes, for which the name Wandonia haliotis gen. nov., sp. nov. is proposed. The type strain is Haldis $-1^{\top}\left(=\right.$ KCTC $22610^{\top}=$ NBRC $\left.105642^{\top}\right)$.
\end{abstract}

The family Cryomorphaceae, within the phylum Bacteroidetes, includes five genera of marine origin: Brumimicrobium, Cryomorpha, Crocinitomix (Bowman et al., 2003), Owenweeksia (Lau et al., 2005) and Lishizhenia (Lau et al., 2006), and the freshwater genus Fluviicola (O'Sullivan et al., 2005). Members of the family Cryomorphaceae cannot utilize carbohydrates and require complex organic compounds for growth (Bowman et al., 2003; Lau et al., 2005; O'Sullivan et al., 2005). Molecular phylogenetic studies have found that phylotypes related to the family Cryomorphaceae are associated with phytoplankton blooms (Pinhassi et al., 2004; Grossart et al., 2005). In the process of investigating bacterial communities in abalone (Haliotis discus) under aquaculture for food, a novel Gram-stain-negative bacterium producing yelloworange pigments was isolated and investigated using a polyphasic approach.

The GenBank/EMBL/DDBJ accession number for the 16S rRNA gene sequence of strain Haldis- $1^{\top}$ is FJ424814.
Strain Haldis- $1^{\mathrm{T}}$ was isolated from abalone flesh samples collected off the southern coast of Wando $\left(34^{\circ} 18^{\prime} \mathrm{N} 126^{\circ}\right.$ $45^{\prime}$ E) in Korea by using a standard serial dilution plating method and incubation on marine agar 2216 (MA; Difco) at $25{ }^{\circ} \mathrm{C}$ for 5 days. Subcultivation was routinely performed on $\mathrm{LB}$ agar at $30{ }^{\circ} \mathrm{C}$ for 3 days under aerobic conditions and the strain was stored at $-80{ }^{\circ} \mathrm{C}$ in marine broth (MB; Difco) supplemented with $15 \%(\mathrm{v} / \mathrm{v})$ glycerol for preservation.

Sequencing of the $16 \mathrm{~S}$ rRNA gene of strain Haldis- $1^{\mathrm{T}}$ was carried out as described by Lane (1991). The almost fulllength (1480 nt) 16S rRNA gene sequence was compared with sequences from GenBank using the BLAST program (http://www.ncbi.nlm.nih.gov/BLAST/) to determine an approximate phylogenetic affiliation, and aligned with sequences of closely related organisms by using the CLUSTAL W software program (Thompson et al., 1994). Phylogenetic trees were reconstructed by using the neighbour-joining, maximum-likelihood and maximum-parsimony algo- 
rithms available in the PHYLIP software package, version 3.6 (Felsenstein, 2002). The resulting tree topologies were evaluated by using bootstrap analysis based on 1000 resampled datasets with the PHYLIP package. Sequence similarity values between the novel isolate and related strains were evaluated using the Nucleotide Similarity Search program (http://www.ebi.ac.uk/fasta33/nucleotide. html; Pearson \& Lipman, 1988). Neighbour-joining analysis indicated that strain Haldis $-1^{\mathrm{T}}$ formed a distinct phylogenetic line within the family Cryomorphaceae, related to the genera Lishizhenia, Fluviicola, Brumimicrobium, Crocinitomix and Owenweeksia with a low bootstrap value, meaning that the phylogenetic topology is not stable (Fig. 1). Comparative analysis of $16 \mathrm{~S}$ rRNA gene sequences showed that the isolate was most closely related to Lishizhenia caseinilytica UST040201-001 ${ }^{\mathrm{T}}$ and Fluviicola taffensis RW262 ${ }^{\mathrm{T}}$ with 92.5 and $92.4 \%$ sequence similarity, respectively. These data suggested that strain Haldis- $^{\mathrm{T}}$ represents a novel genus within the family Cryomorphaceae.

The following tests were performed on strain Haldis- $1^{\mathrm{T}}$. Growth temperature was examined on LB agar at $5-45{ }^{\circ} \mathrm{C}$ in $5{ }^{\circ} \mathrm{C}$ increments. The $\mathrm{pH}$ range for growth was determined in LB broth adjusted to $\mathrm{pH} 5.0-10.0$ in 0.5 $\mathrm{pH}$ unit increments. The $\mathrm{pH}$ was adjusted prior to sterilization by the addition of $\mathrm{HCl}$ or $\mathrm{NaOH}$ and measured again after sterilization. $\mathrm{NaCl}$ requirement and tolerance were determined in the presence of $0-10 \%(\mathrm{w} / \mathrm{v})$ $\mathrm{NaCl}$ (at $1 \%$ intervals) in LB broth. Gram staining was performed using the bioMérieux Gram Stain kit according to the instructions of the manufacturer. Cell morphology and flagellar and gliding motility were studied using phasecontrast microscopy and transmission electron microscopy (JEM-1010; JEOL) as described previously (Bernardet et al., 2002; Jeon et al., 2004). Oxidase activity was tested by oxidation of $1 \%(\mathrm{w} / \mathrm{v})$ tetramethyl-p-phenylenediamine (Merck) and catalase activity was evaluated by the production of oxygen bubbles in $3 \%(\mathrm{v} / \mathrm{v})$ aqueous hydrogen peroxide solution. The production of flexirubin-type pigments was investigated using the $\mathrm{KOH}$ test according to the method of Fautz \& Reichenbach (1980). Nitrate reduction was assessed according to the method of Lányí (1987) and acid production from carbohydrates was tested as described by Leifson (1963). Anaerobic growth was assessed on LB agar under anaerobic (with 4-10\% $\mathrm{CO}_{2}$ ) conditions using the GasPak Plus system (BBL) at $30{ }^{\circ} \mathrm{C}$ for 15 days. Hydrolysis of aesculin, Tween 80, Tween 20, casein, urea, tyrosine, starch and CM-cellulose was investigated on LB agar after 7 days of incubation at $30{ }^{\circ} \mathrm{C}$,

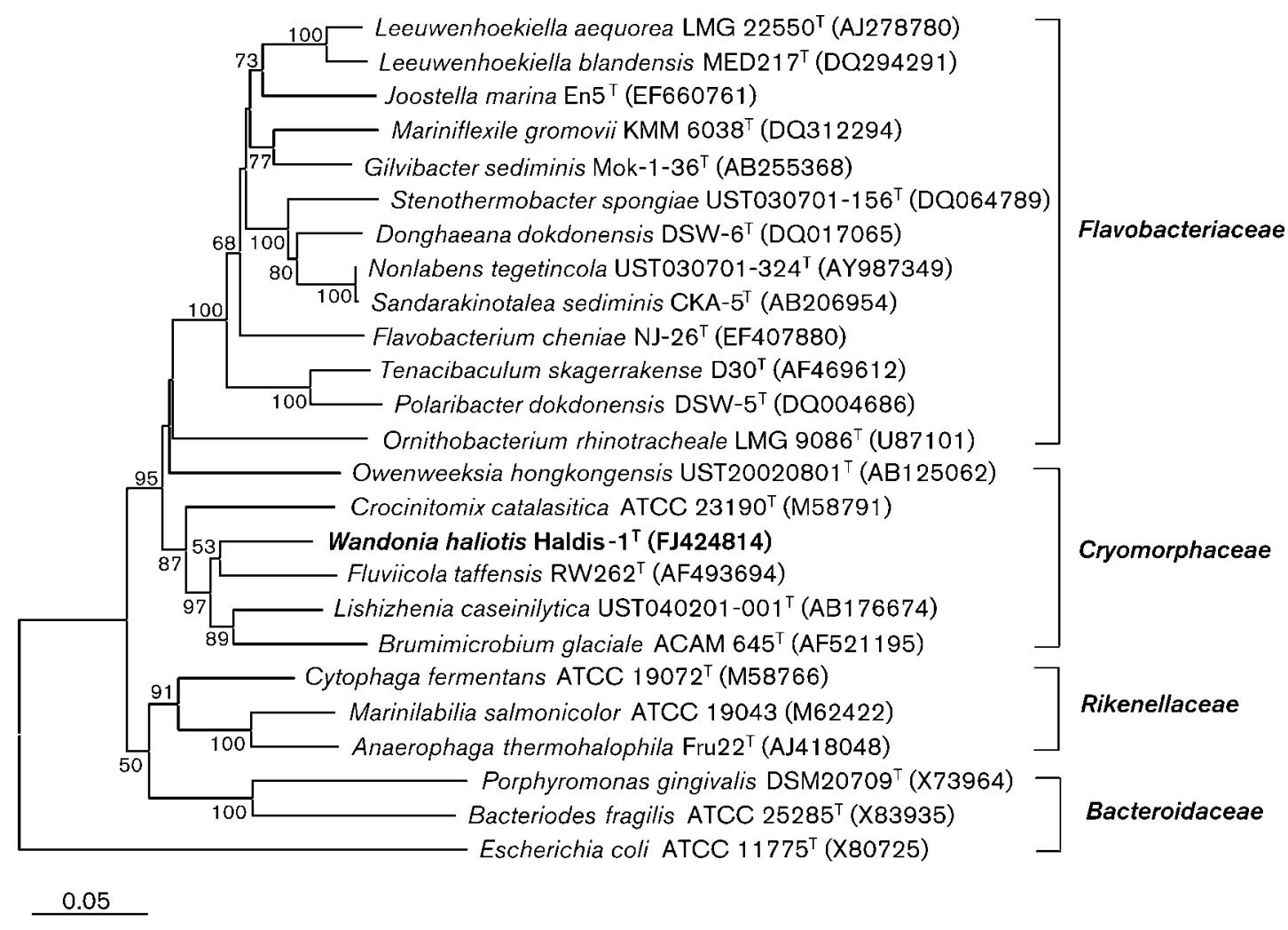

Fig. 1. Neighbour-joining phylogenetic tree reconstructed based on 16S rRNA gene sequences showing the relationships of strain Haldis $-1^{\top}$ and related taxa within the phylum Bacteroidetes. Bootstrap percentages (based on 1000 replicates) greater than $50 \%$ are shown at branch points. Escherichia coli ATCC $11775^{\top}$ (accession no. X80725) was used as an outgroup. Bar, 0.05 substitutions per nucleotide position. 
according to the methods described by Lányí (1987) and Smibert \& Krieg (1994). Additional enzymic activities were determined using the API ZYM kit, as recommended by the manufacturer (bioMérieux), with incubation for 2 days at $30{ }^{\circ} \mathrm{C}$. Antibiotic susceptibility tests were performed in duplicate as described by Reva et al. (1995) using filterpaper discs ( $8 \mathrm{~mm}$ diameter; Whatman) containing the following antibiotics: ampicillin $(10 \mu \mathrm{g})$, polymyxin $\mathrm{B}$ $(100 \mathrm{U})$, streptomycin $(50 \mu \mathrm{g})$, penicillin $\mathrm{G}(10 \mathrm{U})$, chloramphenicol $(100 \mu \mathrm{g})$, gentamicin $(30 \mu \mathrm{g})$, tetracycline $(30 \mu \mathrm{g})$, kanamycin $(30 \mu \mathrm{g})$, lincomycin $(15 \mu \mathrm{g})$, carbenicillin $(100 \mu \mathrm{g})$ and novobiocin $(50 \mu \mathrm{g})$. The phenotypic characteristics of strain Haldis- $1^{\mathrm{T}}$ are listed in Table 1 and in the genus and species descriptions.

The total cellular fatty acid composition of strain Haldis- $1^{\mathrm{T}}$ was analysed according to the instructions of the Microbial Identification System (MIDI; Microbial ID) using cells grown on tryptic soy agar at $30{ }^{\circ} \mathrm{C}$ for 3 days (Table 2). Analysis of isoprenoid quinones was carried out using the methods described by Komagata \& Suzuki (1987). The DNA $G+C$ content of strain Haldis- $1^{\mathrm{T}}$ was determined using an HPLC fitted with a reversed-phase column (GROM-SIL 100 ODS-2FE; GROM) according to the method of Tamaoka \& Komagata (1984). The major respiratory lipoquinone was menaquinone-7 (MK-7), which was distinct from the menaquinone-6 (MK-6) found in Owenweeksia hongkongensis UST20020801 ${ }^{\mathrm{T}}$ of the family Cryomorphaceae.

On the basis of phenotypic, genotypic and phylogenetic data, strain Haldis- $1^{\mathrm{T}}$ is considered to represent a novel genus and species within the family Cryomorphaceae, for which the name Wandonia haliotis gen. nov., sp. nov. is proposed.

\section{Description of Wandonia gen. nov.}

Wandonia (Wan.do'ni.a. N.L. fem. n. Wandonia named after Wando, an island located on the Southern Sea in Korea, from where the type strain of the type species was isolated).

Cells are strictly aerobic, Gram-stain-negative, rod-shaped. Oxidase- and catalase-positive. Cell mass is pigmented yellow-orange and flexirubins are synthesized. Cells do not utilize carbohydrate. The cellular fatty acid profiles contain a high proportion of branched saturated fatty acids (mainly iso- $\mathrm{C}_{15: 0}$ ), hydroxy fatty acids (mainly $\mathrm{C}_{15: 0} 2-\mathrm{OH}$ ), and saturated fatty acids $\left(\mathrm{C}_{15: 0}\right)$. As determined by $16 \mathrm{~S}$ rRNA gene sequence analysis, the genus Wandonia is a member of the family Cryomorphaceae in the phylum Bacteroidetes. The type species is Wandonia haliotis.

Table 1. Phenotypic characteristics that differentiate strain Haldis- $1^{\top}$ from related type species of genera of the family Cryomorphaceae

Strains: 1, Haldis- $1^{\mathrm{T}}$ (data from this study); 2. Fluviicola taffensis RW262 ${ }^{\mathrm{T}}$ (data from O'Sullivan et al., 2005); 3, Lishizhenia caseinilytica UST040201-001 ${ }^{\mathrm{T}}$ (data from Lau et al., 2006); 4, Brumimicrobium glaciale IC156 ${ }^{\mathrm{T}}$ (data from Bowman et al., 2003); 5. Crocinitomix catalasitica NCIMB $1418^{\mathrm{T}}$ (data from Bowman et al., 2003). +, Positive; -, negative; V, variable; W, weakly positive; ND, data not available; A, aerobic; F, facultatively anaerobic.

\begin{tabular}{|c|c|c|c|c|c|}
\hline Characteristic & 1 & 2 & 3 & 4 & 5 \\
\hline Habitat & Marine & Fresh water & Marine & Marine & Marine \\
\hline Cell size $(\mu \mathrm{m})$ & $1-2$ & $1.5-5.7$ & $0.5-3.8$ & $1-3$ & $3-100$ \\
\hline Colour of cell mass & Yellow-orange & Yellow-orange & Orange & Orange & Yellow \\
\hline Gliding motility & + & + & - & - & - \\
\hline \multicolumn{6}{|l|}{ Growth on/at: } \\
\hline $25^{\circ} \mathrm{C}$ & + & + & + & $\mathrm{v} / \mathrm{w}$ & + \\
\hline $42{ }^{\circ} \mathrm{C}$ & + & - & - & - & - \\
\hline $1 \% \mathrm{NaCl}$ & + & - & + & + & + \\
\hline $6 \% \mathrm{NaCl}$ & + & - & + & - & - \\
\hline Metabolism & $\mathrm{A}$ & A & A & $\mathrm{F}$ & A \\
\hline Oxidase & + & - & + & - & - \\
\hline Flexirubin reaction & + & + & - & - & - \\
\hline Glucose utilization & - & - & - & + & - \\
\hline \multicolumn{6}{|l|}{ Degradation of: } \\
\hline Gelatin & + & $\mathrm{w}$ & + & - & - \\
\hline Casein & + & ND & + & - & - \\
\hline DNase & - & + & - & - & - \\
\hline Phosphatase & + & ND & + & + & - \\
\hline Nitrate reductase & - & - & - & + & - \\
\hline DNA G $+\mathrm{C}$ content $(\mathrm{mol} \%)$ & 38.1 & 37.2 & 35.8 & $38-40$ & 35 \\
\hline
\end{tabular}


Table 2. Cellular fatty acids that differentiate strain Haldis $-1^{\top}$ from the type species of genera of the family Cryomorphaceae

Strains: 1, Haldis- $1^{\mathrm{T}}$ (data from this study); 2, Fluviicola taffensis RW262 ${ }^{\mathrm{T}}$ (data from O'Sullivan et al., 2005); 3, Lishizhenia caseinilytica UST040201-001 ${ }^{\mathrm{T}}$ (data from Lau et al., 2006); 4, Brumimicrobium glaciale $\mathrm{IC} 156^{\mathrm{T}}$ (data from Bowman et al., 2003); 5, Crocinitomix catalastica NCIMB $1418^{\mathrm{T}}$ (data from Bowman et al., 2003). Fatty acids amounting to less than $0.5 \%$ in all species are not shown. tr, Trace amount $(<0.5 \%)$; - , not detected.

\begin{tabular}{|c|c|c|c|c|c|}
\hline Fatty acid & 1 & 2 & 3 & 4 & 5 \\
\hline \multicolumn{6}{|l|}{ Saturated } \\
\hline $\mathrm{C}_{13: 0}$ & 1.0 & $\operatorname{tr}$ & $\operatorname{tr}$ & 0.5 & - \\
\hline $\mathrm{C}_{14: 0}$ & 4.3 & 3.2 & 1.6 & 1.5 & $\operatorname{tr}$ \\
\hline $\mathrm{C}_{15: 0}$ & 10.7 & 7.5 & - & 2.9 & 29.3 \\
\hline $\mathrm{C}_{16: 0}$ & 1.3 & 3.0 & 0.5 & 1.9 & 1.8 \\
\hline \multicolumn{6}{|c|}{ Saturated branched-chain } \\
\hline iso- $\mathrm{C}_{15: 0}$ & 38.6 & 44.2 & 44.0 & 36.4 & 36.3 \\
\hline iso- $\mathrm{C}_{15: 1}$ & - & - & 34.8 & - & - \\
\hline iso- $\mathrm{C}_{15: 1} \mathrm{G}$ & 3.7 & - & - & - & - \\
\hline \multicolumn{6}{|c|}{ Unsaturated branched-chain } \\
\hline iso- $\mathrm{C}_{15: 1} \omega 10 c$ & - & 11.8 & - & - & 10.9 \\
\hline anteiso- $\mathrm{C}_{15: 1} \omega 10 c$ & - & - & - & 45.0 & - \\
\hline \multicolumn{6}{|l|}{ Monounsaturated } \\
\hline $\mathrm{C}_{15: 1} \omega 11 c$ & - & 1.2 & - & - & 8.3 \\
\hline $\mathrm{C}_{16: 1} \omega 12 c$ & - & 4.9 & - & - & 4.4 \\
\hline \multicolumn{6}{|l|}{ Hydroxy } \\
\hline $\mathrm{C}_{14: 0} 2-\mathrm{OH}$ & 1.8 & - & - & - & - \\
\hline $\mathrm{C}_{15: 0} 2-\mathrm{OH}$ & 20.3 & - & - & - & - \\
\hline $\mathrm{C}_{16: 0} 2-\mathrm{OH}$ & 1.1 & - & - & - & - \\
\hline iso- $\mathrm{C}_{15: 0} 2-\mathrm{OH}$ & - & 3.5 & - & - & - \\
\hline $\mathrm{C}_{15: 0} 3-\mathrm{OH}$ & 1.7 & - & - & - & - \\
\hline iso- $\mathrm{C}_{15: 0} 3-\mathrm{OH}$ & - & 0.5 & 2.5 & - & 1.0 \\
\hline $\mathrm{C}_{16: 0} 3-\mathrm{OH}$ & 2.1 & - & 0.5 & - & - \\
\hline iso- $\mathrm{C}_{17: 0} 3-\mathrm{OH}$ & 5.0 & 12.3 & 9.3 & - & 3.3 \\
\hline Summed feature $3^{*}$ & 8.4 & - & 2.0 & - & - \\
\hline
\end{tabular}

${ }^{*}$ Summed features represent groups of two or three fatty acids which could not be separated by GLC with the MIDI system. Summed feature 3 contains $\mathrm{C}_{16: 1} \omega 7 c$ and/or iso- $\mathrm{C}_{15: 0} 2-\mathrm{OH}$.

\section{Description of Wandonia haliotis sp. nov.}

Wandonia haliotis (ha.li.o'tis. N.L. n. Haliotis scientific name of a genus; N.L. gen. n. haliotis of Haliotis, referring to the isolation of the type strain from Haliotis discus).

Exhibits the following characteristics in addition to those given in the genus description. Cells are $0.2-0.3 \mu \mathrm{m}$ wide and $2-5 \mu \mathrm{m}$ long. On LB medium, colonies are 1.0 $3.0 \mathrm{~mm}$ in diameter, circular, flat and transparent. Catalase- and oxidase-positive. Growth occurs at 25$42{ }^{\circ} \mathrm{C}$, with an optimum at $30-37{ }^{\circ} \mathrm{C}$. Negative for nitrate and nitrite reduction. Indole is not produced. Negative for $\beta$-galactosidase and urease activity. Can hydrolyse casein and gelatin, but not DNA, agar, starch, cellulose or aesculin. Acid is not produced from glucose. Does not utilize glucose, arabinose, mannose, mannitol, $\mathrm{N}$-acetyl- glucosamine, maltose, gluconate, caprate, adipate, malate, citrate or phenyl acetate. In the API ZYM kit, alkaline phosphatase, esterase (C4), esterase lipase (C8), leucine arylamidase, valine arylamidase, cystine arylamidase, trypsin, acid phosphatase and naphthol-AS-BI-phosphohydrolase activities are present, but lipase (C14), $\alpha$ chymotrypsin, $\alpha$-galactosidase, $\beta$-galactosidase, $\beta$-glucuronidase, $\alpha$-glucosidase, $\beta$-glucosidase, $N$-acetyl- $\beta$-glucosaminidase, $\alpha$-mannosidase and $\alpha$-fucosidase activities are absent. Resistant to gentamicin $(10 \mu \mathrm{g})$, kanamycin $(50 \mu \mathrm{g})$, polymyxin $\mathrm{B}(300 \mathrm{U})$, neomycin $(30 \mu \mathrm{g})$ and novobiocin $(5 \mu \mathrm{g})$, but sensitive to ampicillin $(10 \mu \mathrm{g})$, carbenicillin $(100 \mu \mathrm{g})$, erythromycin $(15 \mu \mathrm{g})$, lincomycin $(15 \mu \mathrm{g})$, nalidixic acid $(5 \mu \mathrm{g})$, oleandomycin $(15 \mu \mathrm{g})$, penicillin $\mathrm{G}(10 \mathrm{U})$ and tetracycline $(30 \mu \mathrm{g})$. The major ( $>5 \%$ of total) cellular fatty acids are iso- $\mathrm{C}_{15: 0}, \mathrm{C}_{15: 0} 2$ $\mathrm{OH}, \mathrm{C}_{15: 0}$ and summed feature 3 (comprising $\mathrm{C}_{16: 1} \omega 7 c$ and/or iso- $\left.\mathrm{C}_{15: 0} 2-\mathrm{OH}\right)$. The DNA G $+\mathrm{C}$ content of the type strain is $38.1 \mathrm{~mol} \%$.

The type strain is Haldis- $1^{\mathrm{T}}\left(=\mathrm{KCTC} 22610^{\mathrm{T}}=\mathrm{NBRC}\right.$ $105642^{\mathrm{T}}$ ), which was isolated from abalone (Haliotis discus) under aquaculture in seawater off the Wando coast, Southern Korea.

\section{Acknowledgements}

This study was supported by the Ministry of Maritime Affairs \& Fisheries (Grant No. 20080103402-00).

\section{References}

Bernardet, J. F., Nakagawa, Y. \& Holmes, B. (2002). Proposed minimal standards for describing new taxa of the family Flavobacteriaceae and emended description of the family. Int J Syst Evol Microbiol 52, 1049-1070.

Bowman, J. P., Mancuso Nichols, C. \& Gibson, J. A. E. (2003). Algoriphagus ratkowskyi gen. nov., sp. nov., Brumimicrobium glaciale gen. nov., sp. nov., Cryomorpha ignava gen. nov., sp. nov. and Crocinitomix catalasitica gen. nov., sp. nov., novel flavobacteria isolated from various polar habitats. Int J Syst Evol Microbiol 53, 13431355.

Fautz, E. \& Reichenbach, H. (1980). A simple test for flexirubin-type pigments. FEMS Microbiol Lett 8, 87-91.

Felsenstein, J. (2002). PHYLIP (phylogeny inference package), version 3.6a. Distributed by the author. Department of Genome Sciences, University of Washington, Seattle, USA.

Grossart, H. P., Levold, F., Allgaier, M., Simon, M. \& Brinkhoff, T. (2005). Marine diatom species harbour distinct bacterial communities. Environ Microbiol 7, 860-873.

Jeon, C. O., Park, W., Ghiorse, W. C. \& Madsen, E. L. (2004). Polaromonas naphthalenivorans sp. nov., a naphthalene-degrading bacterium from naphthalene-contaminated sediment. Int J Syst Evol Microbiol 54, 93-97.

Komagata, K. \& Suzuki, K. (1987). Lipid and cell-wall analysis in bacterial systematics. Methods Microbiol 19, 161-207.

Lane, D. J. (1991). 16S/23S rRNA sequencing. In Nucleic Acid Techniques in Bacterial Systematics, pp. 115-175. Edited by E. Stackebrandt \& M. Goodfellow. Chichester: Wiley. 
Lányí, B. (1987). Classical and rapid identification methods for medically important bacteria. Methods Microbiol 19, 1-67.

Lau, K. W. K., Ng, C. Y. M., Ren, J., Lau, S. C. L., Qian, P.-Y., Wong, P.-K., Lau, T. C. \& Wu, M. (2005). Owenweeksia hongkongensis gen. nov., sp. nov., a novel marine bacterium of the phylum 'Bacteroidetes'. Int J Syst Evol Microbiol 55, 1051-1057.

Lau, K. W. K., Ren, J., Wai, N. L. M., Qian, P.-Y., Wong, P.-K. \& Wu, M. (2006). Lishizhenia caseinilytica gen. nov., sp. nov., a marine bacterium of the phylum Bacteroidetes. Int J Syst Evol Microbiol 56, 2317-2322.

Leifson, E. (1963). Determination of carbohydrate metabolism of marine bacteria. J Bacteriol 85, 1183-1184.

O’Sullivan, L. A., Linna, J., Humphreys, G., Weightman, A. J. \& Fry, J. C. (2005). Fluviicolor taffensis gen. nov., sp. nov., a novel freshwater bacterium of the family Cryomorphaceae in the phylum 'Bacteroidetes'. Int J Syst Evol Microbiol 55, 2189-2194.

Pearson, W. R. \& Lipman, D. J. (1988). Improved tools for biological sequence comparison. Proc Natl Acad Sci U S A 85, 24442448 .
Pinhassi, J., Sala, M. M., Havskum, H., Peters, F., Guadayol, O., Malits, A. \& Marrase, C. (2004). Changes in bacterioplankton composition under different phytoplankton regimens. Appl Environ Microbiol 70, 6753-6766.

Reva, O. N., Vyunitskaya, V. A., Reznik, S. R., Kozachko, I. A. \& Smirnov, V. V. (1995). Antibiotic susceptibility as a taxonomic characteristic of the genus Bacillus. Int J Syst Bacteriol 45, 409-411.

Smibert, R. M. \& Krieg, N. R. (1994). Phenotypic characterization. In Methods for General and Molecular Bacteriology, pp. 607-654. Edited by P. Gerhardt, R. G. E. Murray, W. A. Wood \& N. R. Krieg. Washington, DC: American Society for Microbiology.

Tamaoka, J. \& Komagata, K. (1984). Determination of DNA base composition by reversed-phase high-performance liquid chromatography. FEMS Microbiol Lett 25, 125-128.

Thompson, J. D., Higgins, D. G. \& Gibson, T. J. (1994). CLUSTAL W: improving the sensitivity of progressive multiple sequence alignment through sequence weighting, position-specific gap penalties and weight matrix choice. Nucleic Acids Res 22, 4673-4680. 